\section{DE DE GRUYTER OPEN}

J oumal of Interc ultural Management Vol. 5, No. 1, March 2013, pp. 29-50

DOI 10.2478/joim-2013-0003

Jan Rek

University of Social Sc iences, Lodz

\title{
On certain limitations of the globalization discourse in Poland: a cultural studies perspective
}

\begin{abstract}
The assumption that globalization means the relatively free circulation of goods, texts, people, ideas and information on a global scale, as well as the circulation of concepts of globalization and views on it, is the starting point of this essay. Its main aim is to define the salient features of the Polish globalization discourse by comparing it with the analogous discourse in the West, where it was first conceptualized.

The conclusions arising from a closer analysis of the Polish discourse are as follows: regardless of whether methodological nationalism is considered a fundamental limitation upon any social science research determining its general priorities, such discourse privileges traditional concepts of nation-state as a mode of sovereignty territorially legitimated and/or state-centrism on a world scale, which rest upon resentments motivated by national memories of an inauspicious past and are of emotional, psychologically enduring character.
\end{abstract}

Key-words: globalization discourse, cultural studies perspective.

Raymond Williams once wrote about key words. These are words referring to various phenomena frequently used in debates and discussions of every academic discipline. They seem to function there on special terms. They are used in a special way by users of a given language because they seem to have certain qualities other words do not possess. Key terms reflect

the vocabulary of a crucial area of social and cultural discussion, which has been inherited within precise historical and social conditions and which has to be made at once conscious and critical - subject to change as well as to continuity - if the millions of people in whom it is active are to see it as active: 
not as tradition to be learned, nor as consensus to be accepted, nor as a set of meanings which, because it is 'our language', has a natural authority; but as a shaping and reshaping in real circumstances and from profoundly different and important points of view: a vocabulary to use, to find our own ways in, to change as we find it necessary to change it (..).

[Williams 1983, pp. 24-25]

It means that such terms do not have a neutral character. They are important in their own way since they perform some vital functions. They are sort of markers signaling both the condition and the form of social relations in a given period, and the condition and the shape of culture. Even more, our choice of how we use them in communication with our partners also reveals the ways of our thinking. In a sense they 'disclose' us, for frequently, independently of the speaker's intentions, or even independently of whether he or she is willing to express their intentions out loud, the markers reveal the speaker's preferences and interpretational strategies by means of which he or she states some values, and defines them together with other members of the community he or she belongs to. Globalization is such a key word.

For quite some time we have found ourselves preoccupied by that single word, which we were hearing a lot. It seems that we have heard it in two senses. One is relating to flows over a distance and/or time. What it emphasizes is getting beyond the static exchange models, free and reciprocal flows of goods, people, capital and ideas on a global scale. In other words, the phenomena are connected with various sorts of exchange on a scale that does not fit in the predetermined and relatively commonly accepted boundaries. Or, simply: we observe that the limits of our planet define its borderline. That is, surely, what Ulrich Beck [1992, pp. 10-11] meant when he wrote:

the fact that we are increasingly living in a world society in the sense that the notion of closed spaces has become illusionary... from now on nothing which happens on our planet is only a limited local event.

Globalization is a term which simultaneously connotes still other senses. For it may appear that the way it is used by today's anthropologists, sociologists of culture or media scholars is a simple act of 'revaluing' their on-going research by means of a trendy 'staffage'. In other words, research labeled in such a way may falsely suggest it is an example of a fresh and revealing recognition of social problems that have emerged only nowadays [Massem 1993, p. 60]. Or, in order to sustain the same critical perspective, it may be stated that globalization only seemingly means the birth of a new grand narration functioning on terms of commonly accepted way of clarifying the collective historical experience, and acting as a general pattern for all sorts of stories [Stephens, McCallum 1998, pp. 3-5]. Since the provocative declaration of Lyotard, proclaiming the 
delegitimization of scientific thought and research procedures, as well as questioning the sense of existence of higher learning institutions [Lyotard 1997, pp. 110-115], such lack of a general pattern has been worrying. The absence of the pattern was taking its toll for, by demolishing the belief in the power of human mind held since the Enlightment, it erroded the feeling of certainty and activated the inclination to relativize even the obvious truths. In such a situation the concept of globalization was of assistance mainly in the sphere of psychology: it was a sort of an antidote for all the disillusionment caused by the postmodernist skepticism stimulated by epistemological chaos, and also the disappointments triggered by the conviction that vital potentials of the development of art, whose driving force was the pursuit of originality, had bee depleted. Globalization was - and still is - more of a myth and a hypothetical project of the open world. For the inequalities in the development, or a different level of the economic advancement of individual countries - taking into consideration only those aspects - make the vision of global economy, that is the structure of multi-faceted relations of comprehensive character, just an ideal type, whose incorporating into real life must take more time before it becomes the accomplished fact [Hirst, Thompson 2000, p. xiii].

Even if one admits, though, that the skepticism and the reserve expressed here are well-grounded, for, as of now, the vision of a global community consisting of peoples inhabiting our planet, has not really shaped up [Albrow 1990, p. 9], it must be agreed that the globalization discourse has united the representatives of many fields and disciplines. Empirically verifiable facts concerning transformations of sociallife exerted pressure on scholars to take the floor. The researchers of globalization processes frequently put forward issues which, when treated separately as incidental, passed unnoticed. They gained importance when they could be arranged in some meaningful ensemble: when individual examples and/or incidental cases, though geographically distant, linked with one another, thus creating longer chains of mutual interactions. Then they more clearly reflect phenomena of general character, fundamental for the times when they manifested themselves.

Back in the 1980s, Raymond Williams quite ironically commented on the fact of formation of the new type of relations between man and the world of things, and it was hard to suppose that from those observations, or at least on the basis of them, the concept of dynamic identity and 'long-distance nationalism' would be born and developed. Here is what he wrote:

There was this Englishman who worked in the London office of a multinational corporation based in the United States. He drove home one evening in his Japanese car. His wife, who worked in a firm which imported German kitchen equipment, was already at home. Her small Italian car was often quicker 


\title{
32 Jan Rek
}

through the traffic. After a meal which included New Zealand lamb, Californian carrots, Mexican honey, French cheese and Spanish wine, they settled down to watch a programme on their television set, which was made in Finland. The programme was a retrospective celebration of the war to recapture the Falkland Islands. As they watched it they felt very warmly patriotic, and very proud to be British.

[Williams 2000, p. 177]

By analogy, at the beginning of the $20^{\text {th }}$ century it was hard to believe in the prophecies of the Italian poet, the ideological founder of Futurism, Filippo Marinetti, who predicted that the speed would become one of the basic elements shaping modern culture and art, and thus, half a century later, giving in a way an impulse to formulate the concept of the death of distance by Frances Cairncross [Cairncross 1997].

\begin{abstract}
An ordinary man can in a day's time travel by train from a little dead town of empty squares, where the sun, the dust and the wind amuse themselves in silence, to a capital city bristling with lights, gestures and street cries. By reading a newspaper the inhabitant of a mountain village can tremble each day with anxiety, following insurrection in China [and] the heroic dog-sleds of the polar explorers. The timid, sedentary inhabitant of any provincial town can indulge in the intoxication of danger by going to the cinema and watching a great hunt in the Congo... Then back in his bourgeois bed he can enjoy the distant expressive voice of a Caruso or Burzio.
\end{abstract}

[Marinetti, quoted in Miller 1998, p. 105]

Later globalization processes gathered pace and their latest phase has been taking place before the eyes of today's young generations, the beneficiaries of successive waves of the technological revolution [Robertson 1992, pp. 57-60]. New threads appeared in the globalization discourse which in some measure resulted from direct experience. Or, more precisely, they referred to empirically ascertainable phenomena which, then, became subjects of in-depth study. This is how the concept of deterritorialization underlining the weakening role and significance of territory in shaping social relationships and practices, was born. It drew conclusions from the practices undertaken by diaspora communities members such as Turkish guest workers, watching Turkish films in their German flats, of whom wrote Arjun Appadurai [2000, p. 4]. It also legitimized Antonio Gramsci's dynamic concept of identity, for whom identity was the subject of personal choices, and not an 'ancestral acquisition', and who, approaching the anti-essentialist critique of the problem, claimed that the identification with multiple identities may be accepted in many cases [Jones 2006, p. 60]. One must admit that, for instance, media coverage of 2010 FIFA World Cup in South Africa highlighting the ethnic diversity of the German national team offered 
important confirmation of the concept (e.g. the headline in "The Baltimore Sun" (July 06, 2010) read: "Foreign-born players give Germany a different look").

Globalization is an on-going process. Obviously, it has created great confusion in the public life. The vision of the world and measures, by means of which we have always described it, suffered the most. For a few centuries the world had seemed to be colonized by human mind, and thus it could have been seen as organized. Since paradigms used in the past lost their previous precision, the clearly defined units became units of fuzzy edges. Regardless of the methodological sympathies they held, scholars representing such fields as, for instance, economics, political sciences or social communication, in their pursuit of conceptualizing the phenomenon of globalization, tended to do one and the same thing: emphasize the effect of homogenization. New technologies enabling mass communication and free flow of people and goods largely contributed to this homogenization [Meyer, Geschiere 1999, p. 3].

Thoughglobalization processesseemendless, theproblem of the consequences they have already incurred became the topic of numerous analyses conducted by social sciences, especially in developed countries ${ }^{1}$. Generally speaking, as Neil Brenner [1999] observes, two attitudes have been formed:

- the conception oriented on state-centrism on a world scale

- the conception of deterritorialization.

In order to outline the framework of both positions, I would like to remark that the first group tries to reconcile the dynamic transformations with the patterns sanctioned by tradition. Or they formulate a thesis that although lifestyle and social practices have been fundamentally changed, the differences in the relation to the previous periods are solely a matter of scale and degree. In other words, the world once seemed to constitute a territorially diverse entity. The traditional image of the world, as the result of map projection of a number of states seen as territorial entities regulating space, reflected the valorization of territory. Each of the elements had its own autonomous character, as having clear and straightforward borders was easily identified. Globalization process has definitely contributed to the acceleration of the flow of goods, capital, people, ideas and information within the geographical space. But as a result of that, the socio-territorial infrastructure has been disturbed, or at least its importance and significance have been profoundly undermined. The erosion of former divisions and differences within the aforementioned net, with their concurrent fluency and changeability, made the contours of the world the only

1 This domination is not accidental. It stems from the fact that developed countries were territories in which globalization processes, motivated by the dynamic development of capitalism, were the first to be initiated (Harley, 1982; 2006; Hutton, Giddens, 2000; Burszta, 2004). Their social and economic significance made them both a research subject and interesting topics for scholarly discussions right from the very beginning. 
permanent line of demarcation. They determined the edges of a global space inhabited by a 'world society', which, in structural respect, was analogical to the previous territorial entities described as nation states [Wallerstein 1988; Robertson 1992].

Globalization as such is indeed an extended variant of a traditional idea of a nation state based on a model elaborated and adopted by virtue of the Peace of Westphalia treaty in 1648. It restored peace throughout nearly the whole of Europe, thus ending the Thirty Years' War, and afterwards raised the matter of a sovereign territory enclosed by predetermined boundaries as a fundamental condition of existence of a nation [Brenner 1999; Appadurai 2003; Wnuk-Lipiński 2004; Kubiak 2007; Jagiełło 2009]. Treating the nation as an undisputed value is, admittedly, a proof of accepting the traditional point of view, but at the same time it is an attempt to theorize on the new global space. This space, as emphasized, contains sets of social living spaces, smaller in scope, but remaining in motion since they have been exposed to unceasing influence of forming globalization processes which change their shapes. The people who live there may move about more or less freely. If, for some reason, they do not take advantage of this possibility, or they are unable to do so, they may still spread the goods they produce, ideas and information.

The followers of the concept of deterritorialization are more radical in their views. They have thoroughly scrutinized the rudiments of past reflection on social world. Such an analysis - especially if conducted in the spirit of deconstructionism - had to lead to conclusions which would question former views and standpoints. But it is not so easy to free oneself from habits and established patterns in thinking and concluding. They are useful or even comfortable, for, by directing the attention towards the conventionalized procedures and accepted decisions, they allow somehow the feeling of safety. Hence, they constitute intellectual barriers which protect the access to new observations and make people repeat the beaten catch-phrases [Wallerstein 1991, p. 1]. Globalization processes, in great measure, freed the spirit of criticism since they brought along the dynamics of transformations on a scale which had never been encountered before. They demolished the long-used paradigms, forced new assessment of social relations and, by revealing the cognitive inertia of the human mind, they forced either the revision of previously held ideas, or taking a resolute standpoint in relation to the new phenomena.

Generally speaking, in the approach of the social sciences to the concept of nation one may trace two types of attitudes. They are based on assumptions which, like a parallax, distort the image of globalization process [Brenner 1999, pp. 45-46].

One of them is spatial fetishism. It manifests itself when we presuppose - not necessarily in a resounding declaration - that space determines social 
relations and it is an autonomous and static phenomenon, as Descartes once wrote. What is more, then we also allows that it is a constant value existing beyond time, that is to say one which is not subject to historical changes, invariable in its characteristics and, which is especially crucial; we allow that it successfully resists any interference of a human factor [Sayer 2000, pp. 109-121; Jessop, Brenner, Jones 2008, pp. 389-401]. Then we claim that the ostentatious attachment to such a stance is an effect of a 'territorial trap' which has underlain the thinking of representatives of social sciences treating about the lives of societies and the ways of their existence. In the face of globalization process it is easier to notice that supporters of this sort of views, in some measure voluntarily, have been 'trapped' as slaves of the assumption that all social and economic activities on the one side, and political and cultural ones on the other, take place within some kind of 'containers'. Each of them seems to be a territorially self-enclosed entity with its own space, in which a man is a guest at most [Taylor 1994, pp. 151-162; Agnew 1994, pp. 53-80].

The second attitude is motivated by methodological territorialism. It is displayed when we assume before the analytical procedure is undertaken, that a nation is located in a territory whose existence precedes in time the existence of the nation. It means that the existence of the territory becomes the condition for the existence of the nation. In other words, this reflection is based on a conviction that a territorial character of an organism called 'nation' is its natural feature which may not be abandoned or disposed of, and only the fact of possessing a territory grants the right for any kind of statehood to form. This kind of attitude characterized the way of thinking about a nation in the $19^{\text {th }}$ century. To a large extent, it was a factor determining not only the ways of operating research tools, but it was setting the borderlines of analyses and defined the horizon of research inference as well [Taylor 1996, pp. 1917-1928; Taylor 2000, pp. 5-32; Scholte 2000, pp. 56-58; Scholte 2008, pp. 1484-1485].

It is beyond doubt that an open discussion on the foundations on which we base our way of thinking about a nation and territory, as well as our thoughts on culture and social relations, is strictly connected with the aforementioned globalization process. On the other hand, however, it may not be excluded that the emergence of voices disturbing the stabilized vision of their formation has released the inclination to revise some presuppositions serving as principles to guide how we live our lives. Clifford Geertz, when characterizing the conjuncture in the sphere of psychology, wrote that in the postmodern age all monopolies and authorities had lost their significance, as a result of which "the golden age of the social science when (...) the basic goal of the enterprise was universally agreed upon (..), has clearly passed" [Geertz 1980, p. 178]. And Zygmunt Bauman emphasized that in postmodern times the intellectual functions as a translator rather than as an arbiter [see Bauman 2000, p. 76]. 
This way or another, a space for discussion has opened - not only in the field of social sciences - and it tackled the problems revealed by globalization, which, because of the technological revolution and, mainly, electronic media, became audible in every corner of the world. In the situation when the progressive pluralization of different discourses encouraged the inclination to undermine the conventional truths of the past, it was easier to free oneself from the terror of geographical units when reflecting upon social or economic relations, or the circulation of media messages. It was easier to pull a face of a naive child and ask: who said that social, economic or cultural phenomena began and end exactly within the territorially enclosed entities, or that they may occur only within the limited framework of the space whose borders are the borders of the nation? Once those questions have been posed, the answer went as follows: contemporary terrorism or ecological movements or feminism are not connected with one specific place on Earth; they may not be locked by the walls of enclaves for such phenomena freely permeate all borders - and this is why they cause problems to those who try to resist them. In these circumstances, Michael Herzfeld could directly pronounce that claiming that the borders of a culture overlap with the borders of a nation is a sign of ideologization of cultural studies. It is evidence of getting involved into strategic goals of the authorities attempting to maintain control over the territory they once governed. [Herzfeld 2005, p. 199; Storey 2003, p. 6].

Gupta and Fergusson wrote about one of fundamental assumptions functioning in the anthropology of culture for a long time:

Of course, the geographical territories that cultures and societies are believed to map onto do not have to be nations. We do, for example, have ideas about culture-areas that overlap several nation-states, or of multicultural nations. On a smaller scale, perhaps, are our disciplinary assumptions about the association of culturally unitary groups (tribes or peoples) with 'their' territories. (..) In all these cases, space itself becomes a kind of neutral grid on which cultural difference, historical memory, and societal organization are inscribed. It is in this way that space functions as a central organizing principle in the social sciences at the same time that it disappears from analytical purview.

[Gupta, Fergusson 1992, pp. 6-7]

These remarks refer to territorial determinism [Ardrey 1966, p. 203; Storey 2003, p. 11], resulting from a long process of familiarization and naturalization - according to which "territorial realities of one or other sort both bound and determine social arrangements" (Appadurai 2003, p. 344]. This type of determinism makes us presume traditionally that:

The multiple displacement effects associated with globalization have had a radical impact on the way communities are 'grounded'. Communities are conventionally 
understood as being bound to specific places. Their identity and cohesion come from relationships that are patterned within a given territory. The strength of community, it is assumed, is dependent on the density and intensity of these relationships. Hence, when people 'move out', it is thought that they left that community or, at best, that their active presence will be transformed into the more passive role of those who just ' $k e e p$ in touch'. Membership of a community is thereby seen in terms of proximity and contact with the centre of that place. The further away from the one is situated, the looser, more irregular, less connected one feels. The further towards the periphery one gets, the more one is regarded as a stranger.

[Papastergiadis 2000, p. 114]

The endeavors discussed here, aiming to disqualify the 'geographical' thinking in social sciences, went hand in hand with the negation of the valid in anthropology of culture logic, which explained the transformations of culture by means of either the principle of linear development or the principle of polar domination. The first principle treated the change in culture as a realization of its inner abilities, albeit stretched in time. The second principle, however, insisted that the change was the effect of a culture clash, as a result of which the winner gained the right to determine the dominating values, and the loser had to conform [Papastergiadis 2000, p.108].

This type of logic is not applicable in the world dominated by globalization processes. Culture phenomena, cross-cultural contacts, migration of people, media hype and clamor flooding the mass audience with a stream of information and concepts, global exchange of goods and services, and financial transfers - all reached such a dynamics that one should be talking about continuous flows [Sinclair et al. 1996; Meyer, Geschiere 1998; Burszta 2004; Appadurai 2003; Hannerz 2006; Castells 2000]. Their origin, frequently, cannot be reduced to a simple relation between the cause and effect, or explained by means of mechanistic models originating straight from Newtonian physics [Papastergiadis 2000, p. 101]. Their trajectories collide with one another, or they pass each other at a distance, or they co-occur right next to one another. In the public sphere, as in economics or media, certain structures and formations of a new type have emerged. They do not possess a solid or complete character. They are like ephemera: they take given shapes, for a short time only, to transform again [Fabian 1992, pp. 191-206]. In such conditions describing changes and continuities is hindered, just as defining the essence and function of a borderline [Roseau 1990; Roseau 1997; Balibar 1998].

These conditions have given rise to the idea of deterrioralization. The concept cumulates all arguments, or rather counter arguments, which, in the field of social sciences, were raised against the 'geographically' oriented sociology and anthropology of culture. By referring to empirical facts which confirm 
- The erosion of a traditional model of a nation [Strange, 1999; Ballinger 2002; Appadurai 2003; Appadurai 2005]

- Unstabilized character of identity influenced by the pressure of sociocultural and political contexts, frequently motivated by economic or prestige factors [Rouse 1995a; Rouse 1995b; Bayart 1996; Bayart 2007]

- Growing phenomenon of migration on a different scale leading to the creation of diaspora communities [Anderson 1994; Mittelman 2000; Glick Schiller, Fouron 2002; Anderson 2002]

- Technologically-secured possibility to experience the world in a mediatized way [Morse 1998; Giddens 2001]

- Creating supranational communities on a global scale- with the lack of direct bonds, but with the active use of imagination and modern technology constituting a territorially independent union and association [Anderson 1997; Anderson 2002; Glick Schiller, Fouron 2002].

this concept breaks the connection between social relations and cultural phenomena, sanctioned by traditions and habits, of the territory on which they are supposed to exclusively exist, or to which they are supposed to be ascribed on the principle of exclusiveness.

Regardless of whether we accept the definition of Anthony Giddens, who described deterrioralization as "the 'lifting out' of social relations from local contexts and their rearticulation across indefinite tracts of time-space" [Giddens 1991, p. 18]2, or that of Nestor G. Canclini, for whom deterrioralization is "the loss of the 'natural' relation between culture with the geographic and social territories, and, at the same time, certain relative, partial territorial relocalizations of old and new symbolic productions" [Canclini 1995, p. 229], the important thing is disembeding from geographic dependencies. The term 'deterrioralization' is ambiguous: it erroneously emphasizes the possibility to completely suspend or even eliminate all sorts of space connections [Scholte 2008, p. 1503].

The globalization discourse stresses clearly that deterrioralization always goes handin hand with reterritorialization: the given social or economic relations or cultural phenomena from one territory are moved to another territory - even if it is hard to determine precisely where the demarking line between them should go - by principle of transfer. The matter of deterritorialization and reterritorialization was explained by Ȯ Tuathail:

Deterritorialization... evokes the challenges posed to the status of territory and, by extension, our territoriality embedded understandings of geography, governance and geopolitics, states, places and the social science, by

2 Although Giddens does not use this term, he writes about a phenomenon which may be described as such. 


\begin{abstract}
planetary communication networks and globalizing tendencies. But it is deceptive when it becomes an answer polemically naming this challenge as a clear disappearance of territoriality. The problematic of deterritorialization is also the problematic of reterritorialization; it is not the presence or absence of state territoriality but its changing status, power and meaning in relationship to postmodern technological constellations, speed machines, and global webs of capitalism."
\end{abstract}

[ Ó Tuathail 1998, p. 82]

Indeed, the trouble is that the former power of influence of territoriality as the foundation of our way of thinking about social relationships and culture, just as, for instance, [our way of thinking] about the transformations of English literature or ethnic tensions of Albanian people, lost its significance. In the face of the progressive globalization and on-going discussions on territorial and postterritorial methodology, territoriality as a norm has become devaluated. This very fact simplified all research oriented on national cultures, and, at the same time, implied painful, political dilemmas, for it undermined the confidence in a state's ability to regulate or, all the more, govern social, economic or cultural life [Scholte 2008, pp. 1484-1485].

At this point, it is worth considering the problem essential for the reasoning in this essay: namely, not only had globalization opened up borders between people living on the planet by enabling the exchange of goods and the flow of various packages woven from words, pictures and sounds. It also facilitated the free flow of opinions and ideas regarding the globalization itself. It is worth mentioning the possibility of confronting all the effects of a research reflection over the social world, which is only just coming into existence. Modern technology let opinions and ideas elaborated in different contexts meet, regardless of the degree of intensity of the globalization process that had activated them. Their multitude and abundance prove that in social sciences different 'dialects', visions and standpoints may flourish [Albrow 1990, p. 8].

For the benefit of this article, I have scrutinized a number of Polish research studies published over the period of the last dozen years, tackling issues connected with globalization. This essay neither pretends to be their detailed register, nor is it a thorough report of all the problems raised by their authors. What I took greatest interest in was determining the character of the globalization discourse conducted in a country which, as a result of a transformation of the political system in 1989, entered upon a path of a rapid economic development, and which, due to those political transformations and processes of democratization, on the one hand - opened up to the world, and on the other - created necessary conditions for a real media revolution. It may seem that this discourse in Poland is not shaped by social practice, but rather by metacritical deliberations on concepts formulated where the results 
of globalization processes are more tangible. Or, to put it differently, Polish globalization discourse is driven, to a greater degree, by theories which have emerged on territories, where globalization processes are a force influencing social life or economic relations, than by social facts induced by globalization.

In the Polish case, the characteristic feature of globalization discourse is a decided preference for topics emerging from concepts oriented on the nation. Two issues are in the lead there: a traditional model of the nation-state, and the matter of national identity [Skarga 1997; Szacki 1997; Szacki 2004; Dziemidok 2002; Bokszański 2005; Golka 2006; Szlachcicowa 2007; Mamzer 2007; Jagiełło 2010].

As Daniel Markowski observed a few years ago, in most cases, when discussing the matter of globalization in the cultural aspect, the supporters of the thesis proclaiming a crisis of the nation-state come from economically developed countries, whereas the supporters of the other thesis, that is to say - one treating about consolidating the national identity - not necessarily within a social formation called 'nation' - come from the developing countries. In the first case, the role of the nation has a declining tendency, and in the second one, the activity and role of the nation are clearly growing [Markowski 2004].

While it is true that such a statement renders the character of the discussions held in the last couple of years among anthropologists of culture and sociologists, it seems to me that it equally strikes with its generality as with its obviousness. It does not take into consideration those contexts which might have been involved in shaping social attitudes and views connected with discussions on social and cultural relations. After all, it is worth reflecting why such dependence exists, why successes in the field of economy are conducive to the birth of liberal ideas, which diminishes the role of the state in the functioning of the nation.

Now, as I presume, the feeling of the economic advancement experienced in daily life evokes, in the sphere of social psychology, a conviction that at this very stage of development the state and its institutions have exhausted their obligations towards their citizens. As a result, they are, to some extent, 'degraded'. But just for 'security and safety needs', or, in other words, to protect against the risk of unfortunate, hard to predict fortuitous events, members of the given community eagerly accept that, despite everything, national institutions should regulate both - personal and social developments - as the necessary evil, even though on clearly limited terms. However, in case of the developing countries, the interference of the state into its citizens' lives does not only reach deeper and tie everyone with a net of limitations and dos and don'ts. What matters more is that although such a restrictive style of governing entails some victims, for it comes at the price of losing a great deal of personal sovereignty, it may often find some quiet social consent. It does find consent, for 
the painful limitation of freedom may be recognized as a sacrifice an individual pays, or rather, is ready to pay, in order to earn the future prosperity. All the more, if, depending on the style of governance, the hope for the era of prosperity is built with the participation of the currently dominating ideology in culture and social life, as Antonio Gramsci demonstrated conclusively [Femia 1975, pp. 29-48; Bennett 2006, pp. 92-99; Ekers 2009, pp. 287-291].

When confronting the Polish and world globalization discourses, it is hard not to notice that the first one - whose foundation are some plots preselected from the other, most often bearing a critical commentary - realizes quite a legible strategy: to promote 'weaker' of 'soft' concepts, which do not perceive globalization as a power destroying the classical model of a nation-state situated on a given territory, within stable borders, and which are not harmful for the traditional views on identity as a stabilized value courageously resisting the attempts of foreign aggressors, thus deserving the admiration and recognition. Hence, the emergence of such voices:

Some contemporary authors who write about national identity claim that the inevitable modernization processes, globalization tendencies and liberalization of social life diminish the significance of the inherited national identity, which currently may be a subject of a free choice. They refer to the examples of cosmopolitically oriented individuals who are happy, among other things, because they function between different cultures, benefitting, at the same time, from their distinct virtues. (...) Yet, I agree with those, who defend the conviction proclaiming the importance and permanence of national identity which- but for a few exceptions concerning representatives of the elite- does not need to be, at least at present, the subject of a free choice.

[Dziemidok 2002, p. 62]

They are accompanied by opinions which, by projecting the future visions of the social world rather than describing its current state, eliminate the risk of making a mistake. Departing from facts, they refer to the future, which may be verifiable only after some time and then will not necessarily be recognized as a violation of truth. Polish scholars even shun choosing such points of view which may be regarded as disloyal, considering the national interest and, in view of the discussion on globalization, take a balanced and careful position. Here's an example:

All the above mentioned arguments in favor of the decrease of the role of nationstate in today's world, and in a more extreme version - its dusk, and eventually - its disappearance, refer to empirically observed tendencies, and cannot be scorned and regarded as unfounded, cassandric prophesies. An assumption that the currently observed tendencies will also last in the future is silently accepted by the believers of the thesis announcing the looming end of nation-states; though it is not obvious (..).

[Wnuk-Lipiński 2004, pp. 163-164] 
Roland Barthes once wrote about ex-nomination: a special technique used by literature or media exposed in a given moment in history to the pressure of a certain 'reason of state', protecting the survival of the constitutional order. Its essence is to oust from the discourse, or camouflage inside it the ideas and views rival to the set of values sanctioned by the hegemonic ideology at a particular time. Or, in other words, their absence in the discourse, often appearing to be the result of an accidental 'oversight' or 'oblivion', in fact results from actions undertaken in a conscious and purposeful manner. The technique being used then is motivated by the conviction that the reasons a given message professes, or which it represents, are irrefutable. What is more, obliterating the position of a narrator by giving an impersonal character to the account, or applying the 'we' position to it, make all other reasons, especially the opposing ones, seem of little importance in the eyes of the recipient. As a result, the on-going discourse simply astounds with 'obviousness'- and, as such, does not necessitate any detailed analyses in order to establish certain conditions under which it is recognized as legitimate. Beyond doubt, these sorts of strategies - trying to maximally soften the persuasive tone of reasoning in favor of the standpoint which the author of the account or narrator identifies with - are meaningmotivated actions [Barthes 1973, p. 138; John Fiske 1987, p. 290].

The fact is that in Polish globalization discourse, globalization ideas of radical character, that is to say those, which question the essential role of a territory in the functioning of nation states, and which are inclined to acknowledge certain identity (no matter of which sort) as an inconstant value, never gained any enthusiasts. Reports treating about them were full of caution, if not doubt. Here, I would like to clearly state that the diagnosis I am making excludes the writing of Zygmunt Bauman. I do so, for most his works are evidence of his true and creative participation in the globalization discourse. But in Polish globalization discourse he functions in an, as if, 'secondary' manner - that is mostly through Polish translations of his English works ${ }^{3}$. A great majority of his writings on social and cultural aspects of globalization process first appeared on the Western European publishing market. Polish editions always come out only a few years later. This 'delay' does not lower their merits, however by abating, or making unclear, their polemic tone in relation to some adversaries representing Western social thought, it deprives them of some sort of 'intertextuality' and discursiveness, thus making them only facts isolated from discussions and polemics of their time [Tester 2004].

The important moment for Polish globalization discourse was the publication in 2005 of Modernity At Large by Arjun Appadurai. The Polish edition had a

3 See his Globalization - the Human Consequences (Cambridge: Polity 1998); Liquid Modernity (Cambridge: Polity 2000); The Individualized Society (Cambridge: Polity 2001); Society Under Siege (Cambridge: Polity 2002). 
foreword written by translator, Zbigniew Pucek. He emphasized the perverse, or to put it more decidedly: break-through character of the theses proclaimed there, among others - the end of geography, deterritorialization, and the uncertain fate of the idea of nation-state in the near future. Although this voice did not reverberate in the public sphere, i.e. it did not induce any open polemics, it still undermines the assumption that we dealt here with the act of de-nomination in Barthes's sense of the term.

Even if we skip the term de-nomination, as one which does not fully fit the above-mentioned context, what we still observe is some unilaterality in reporting on world globalization discourse. This one-sided perspective appears to be an effect of a certain filter applied by Polish participants in the discourse on globalization. It does not really matter whether the shape of public globalization debates in Poland has a decidedly rationalized and intentional character. The source of this limitation, I dare say, is a methodological nationalism, i.e. a relatively stabilized, sanctioned by national tradition, collective memory distilling the manner of expressing past and current contexts or treating research issues connected with the nation and state by social sciences [Wimmer, Glick Schiller $2002]^{4}$.

This kind of nationalism ${ }^{5}$ as a methodological foundation is hardly ever found in the shape of an avowedly formulated programme. Carefully camouflaged, it manifests itself in texts and actions. In order to reconstruct it, one needs to enucleate it first. It seems that it was modeled in the $19^{\text {th }}$ century Europe, tossed by national conflicts. Since then, in social sciences, as well as on the level of common sense, the vision of the world divided into nation-sized communities by a line marking borders of nation-states, has remained in force. Or even more, it has been regarded as something natural and obvious, and confirmed in the social practice: in regular weather service broadcast by all media, in decorating the facades of important institutions and offices with flags, and in publishing information about sports events with the participation of athletes from a given country in daily newspapers. ${ }^{6}$ Through naturalization, it perfectly merged into

4 This term was introduced by a Portuguese sociologist Herminio Martins, who wrote: "methodological nationalism (...) imposes itself in practice with the national community as the terminal unit and boundary condition for the demarcation of problems and phenomena for social science" (Martins, 1974, p. 276). All the same, it must be acknowledged that recently quite a decided criticism of these views has been made by Daniel Chernilo (2007), A Social Theory of the Nation-State: the Political Forms of Modernity Beyond Methodological Nationalism, London: Routledge, pp. 19-20, 160.

5 I have applied the category of 'nationalism' here in an entirely neutral sense, despite all negative connotations it often raises on the grounds of social sciences in Poland.

6 For Michael Billig actions of this sort are signs of forming the so-called 'banal nationalism'. It usually stays in full harmony with methodological nationalism (see Billig, 1995, p. 155). 
the social reality. It blinded the inhabitants of a social world so that they are unable notice its presence or, at least, realize this presence because it becomes a 'glass window', through which they observe the reality.

Methodological nationalism may manifest itself in two ways. It acts as a certain kind of an 'immunological system' that every member of a community called 'nation' is equipped with - through cultural experiences. It allows for the complete disregard of national conditioning he/she is subject to. The other manifestation is more empirically 'tangible'. It reflects the astounding tendency to promote, and reward, topics, values and people of one's own nation in discourses and public debates. This tendency is intensified when, in the field of vision, 'foreign' elements appear as a potential alternative. There are no reasons, whatsoever, to think that this kind of inclination does not concern or influence representatives of social sciences [Wimmer, Glick Schiller 2002, pp. 304-306].

Evidently, the shape of globalization discourse depends on a few more factors besides methodological nationalism. I the first place, on the globalization process itself and its effects, no matter if they have been experienced directly or indirectly. Other deciding agents are cultural differences, historical memory, the manner of social organization ${ }^{7}$ and the degree of ethnic diversity. Hieronim Kubiak has recently added to this set one more element, quite essential in the Polish case, fear psychoses:

Polish fear psychoses, similarly to most psychoses, do not have an endogenous character. They have been formed in certain conditions and they still last: partially by the principle of inertia in social consciousness, and partially as a result of manipulative efforts towards this consciousness undertaken, among other things, in course of educational process. Psychoses act as specific filters, not only those changing the brightness, but also those justifying our relationships with other people. In order to see oneself and the others without any illusion, and to be able to distinguish the essential from the possible, one needs to break free from them. Undoubtedly, it is not a one-time endeavor, but a meandrous process."

[Kubiak 2007, p. 375]

Historically motivated resentments - especially if they become a tool of historical politics pursued in the shade of an ideology dominating in a given period - in the context of the previously mentioned conditionings, require quite some heroism, also in the sphere of research, in order to agree (or even to talk about out loud) with those ideas which ruin the centuries-old attachment to a given place on Earth, passing as a virtue and measure of civic loyalty at the same time. Or, to accept an opinion that the existence of a community of a supranational character on a great scale which, for instance, has been constituted

7 Compare Gupta's and Fergusson's comments above. 
in recent years by Facebook users, is not only a matter of imagination, and that relationships between members of this community-determining in some sense its cohesion, and not having much to do with any pride or ethnic background - may be established and then maintained long-distance by means of certain technological devices. It seems that accepting such a point of view would be a gesture of good will going beyond the common decency, and, at the same time, it would mean undue forbearance for social practices currently undertaken. Or, to rephrase the problem, gestures of such kind would verge on the acts of heroism, for sooner or later they would have to lead to disloyalty to the valid, or rather established and maintained myth of national unity, which imposes onto its members called 'citizens' a moral obligation to take part in, for example, ritualized social practices, often with a participation of an orchestra, and with a military parade being an important item on the agenda. It cannot be excluded that the possible reserve, or even aloofness, in realizing such patterns, could be received by fellow countrymen professing the norm entrenched in tradition as an act of betrayal in relation to the reportedly vital national interest, for it would be the clear evidence of preferring the 'alien'- as the cosmopolitan one, to the 'own'- as the domestic one. Rejecting the pattern which, in certain contexts, is treated as a norm, usually meets with ostracism in social life and engenders the atmosphere of hostility. In Polish debates on globalization there is, for the time being, neither courage, nor 'political will', if one decides to apply the journalistic rhetoric, to suspend or even modify the pattern. You may ask whether this conservative status quo prevails in discussions just because it is too early for the change of the paradigm. Or, perhaps, because the project of the future world operates more in the virtual world than the real one. Only the future holds the settlement to this dispute. The time will then ultimately verify today's hypotheses forecasting the shape of our world in years to come.

I had my reasons to signal the category of faith, at the very end of this essay. Norbert Elias referred to it when he identified the extra-rational sources of social unrest and research quandaries prompted by globalization processes. He rightly wrote that the concept of nation-state, although of relatively recent date, reflects the assumption that it is the highest-ranking survival unit, higher than a clan or tribe. Globalization process, affecting all social relations, favours survival units above the level of nation-state, but at the same time creates some tension resulting from the fact that on-going actions and developments destroy the balance between all social forces at the moment. Thus, some sort of resistance must inevitably take place. To be more specific on the subject, let me recall Elias:

The resistance to the merging of one's own survival unit with a larger unit - or its disappearance into that unit - is undoubtedly due in large part to a particular feeling. 
It is the feeling that the fading or disappearance of a tribe or state as an autonomous entity would render meaningless everything which past generations had achieved and suffered in the framework and in the name of this survival unit. (..) The disappearance of cultural traditions during absorption into a larger unit does in fact mean, in this and similar cases, a kind of collective dying. The great deeds of fathers and mothers who had risked their lives for these traditions are forgotten. The mighty spirits and gods who stood by the tribe in good times and bad are turned into shadowy names which inspire neither fear nor hope. (..) Something similar happens to states which are under pressure to combine at a higher level. As with the tribe, something which possesses high value for many of the people concerned, with which they identify themselves, fades in the transition to the higher level. The identity of the we-image is threatened.." [Elias 2001, pp. 222-223]

\section{And further:}

Seen as a purely intellectual problem, the absorption of one's own we-group into a wegroup of a higher order appears merely as a devaluation of something highly prized. One might say that that is what it is. But it is more than a devaluation. As long as no feelings of personal identity, no we-feelings are associated with the higher-order unit, the fading or disappearance of the lower-order we-group appears in reality as a kind of death threat, a collective distraction and certainly a loss of meaning to the highest degree. If resistance to integration at a higher level is presented as primarily a problem of thought, an intellectual problem, it can never be properly understood. (..) But in most cases the difficulty lies in the fact that intellectual awareness of the logic of integration meets tenacious resistance of emotive ideas which give the integration the character of ruin, a loss that one cannot cease mourning. And in such a situation, one probably does not want to cease mourning.

[Elias 2001, p. 225]

The mechanism producing those fears and the feeling of a likely loss or defeat, and, surely, the feeling of threat that the vision of integration entails, are not based on rational grounds. Historical experiences located in the collective memory create some burdens carried by next generations. How much time do we need for them to disappear and cease to cast a shadow on the vision of the world in the foreseeable future, on the one hand, and on the other, on our thinking about globalization? The sphere of social psychology embraces, among other things, grudges and collective dreams, which really are beliefs. One of them is the project of survival unit which at the moment is quite generally recognized, and, as such, entirely respected by members of a given community. In other words, it is there 'in force'. It is neither easy to give it up, nor to set oneself free from it, since it is characterized by exceptional inertia. It usually lives on and on. Even when it makes no sign at all, and stays 'silent'. Yet, in culture, silence always tells about something, always is meaningful. Listening 
closely to public discourses, it is worth paying careful attention to what is being talked about, as well as to what is not being talked about at all.

\section{References}

Agnew, J., 1994. The Territorial Trap: The Geographical Assumptions of International Relations Theory. Review of International Political Economy, vol. 1, no 1, pp. 53-80.

Albrow, M., 1990. Introduction, [in:] Albrow, M. and King, E. (eds), Globalization, Knowledge, and Society: Readings from International Sociology, London: Sage, pp. 5-13.

Anderson, B., 1991. Imagined communities: Reflections on the growth and spread of nationalism, New York and London: Verso.

Anderson, B., 1992. The New World Disorder, New Left Review, no 193, pp. 3-13.

Appadurai, A., 2003. Sovereignty without Territoriality: Notes for a Postnational Geography, [in:] Low, S.M. and Lawrence-Zuniga, D. (eds), The Anthropology of Space and Place, Oxford: Blackwell, pp. 337-350.

Appadurai, A., 1996. Modernity At Large: Cultural Dimensions of Globalization, Minneapolis: University of Minnesota Press.

Ardrey, R., 1966. The Territorial Imperative: A Personal Inquiry into the Animal Origins of Property and Nations, New York: Atheneum.

Augé, M., 1995. Introduction to an Anthropology of Supermodernity, (trans. Howe, J.), London: Verso.

Balibar, E., 1998. The Borders of Europe (trans. Swenson, J.), [in:] Pheng Cheah, P. and Robbins, B. (eds), Cosmopolitics: Thinking and Feeling Beyond the Nation (Cultural Politics), Minneapolis: University of Minnesota Press, pp. 216-229.

Ballard; J.G.; 1997. Going somewhere? Airports, [in:] The Observer, 14 September.

Ballinger, P., 2002. History in Exile: Memory and Identity at the Borders of the Balkans, Princeton: Princeton University Press.

Barthes, R., 1973. Mythologies, (trans. Lavers, A.), London: Paladin.

Bayart, J.-F., 2005. The Illusion of Cultural Identity, London: Hurst and Co.

Bayart, J.-F., 2007. Global Subjects. A Political Critique of Globalization, (trans. Brown, A.), Cambridge: Polity.

Bennett, T., 2006. Popular Culture and the 'Turn to Gramsci', [in:] Storey, J. (ed.), Cultural Theory and Popular Culture: A Reader, 3rd ed., London-New York: Pearson/ Prentice Hall, pp. 92-99.

Billig, M., 1995. Banal Nationalism, London: Sage.

Bokszański, Z., 2005. Tożsamości zbiorowe, Warszawa: PWN.

Brenner, N., 1999. Beyond State-Centrism? Space, Territoriality, and Geographical Scale in Globalization Studies, Theory and Society, no 28, pp. 39-78.

Burszta, W.J., 2004. Różnorodność i tożsamość. Antropologia jako kulturowa refleksyjność, Poznań: Wyd. Poznańskie. 


\section{Jan Rek}

Cairncross, F., 1997. The Death of Distance: How the Communications Revolution is Changing Our Lives, Cambridge, MA: Harvard Business School Press.

Canclini, N.G., 1995. Hybrid Cultures: Strategies for Entering and Leaving Modernity, (trans. Chiappari, Ch.L. and Lopez, S.), Minneapolis: University of Minnesota Press.

Castells, M., 2000. The Rise of the Network Society, London-New York: WileyBlackwell.

Chernilo, D., 2007. A Social Theory of the Nation-State: the Political Forms of Modernity Beyond Methodological Nationalism, London: Routledge.

Dziemidok, B., 2002. Tożsamość narodowa i sztuka a nowe media w epoce globalizacji, [in:] Kultura i Społeczeństwo, no 1, pp. 57-71.

Ekers, M. et al.; 2009. Gramsci Lives!, Geoforum, no 40, pp. 287-291.

Fabian, J., 1992. Time and the Work of Anthropology. Critical Essays 1971-1991, London: Routledge.

Femia, J., 1975. Hegemony and Consciousness in the Thought of Antonio Gramsci, Political Studies, 23:1 (March), pp. 29-48.

Fiske, J., 1987. Television Culture, London: Routledge.

Geertz, C., 1985. Blurred Genres: the Refiguration of Social Thought, [in:] Local Knowledge: Further Essays in Interpretive Anthropology, $3^{\text {rd }}$ ed., New York: Basic Books, pp. 19-35.

Giddens, A., 2001. Modernity and self-identity: self and society in the late modern age, Stanford: Stanford University Press.

Glick Schiller, N. and Fouron, G., E., 2002. Long-distance Nationalism Defined, [in:] Vincent, J. (ed.), The Anthropology of Politics: A Reader in Ethnography, Theory and Critique, London: Wiley-Blackwell, pp. 356-365.

Gupta, A. and Fergusson, J., 1992. Beyond Culture: Space, Identity, and the Politics of Difference, Cultural Anthropology, vol. 7, no 1, pp. 6-23.

Hannerz, U., 1996. Transnational connections: Culture, people, places, London: Routledge.

Harvey, D., 1982. The Limits to Capital, Chicago: Chicago University Press.

Harvey, D., 2006. Spaces of Global Capitalism: Towards a Theory of Uneven Geographical Development, London: Verso.

Herzfeld, M., 2005. Cultural Intimacy: Social Poetics in the Nation-State, London: Routledge.

Hirst, P. and Thompson, G., 2000. Globalization in Question: The International Economy and the Possibilities of Governance, $2^{\text {nd }}$ ed., London: Polity.

Hutton, W. and Giddens, A. (eds), 2000. Global Capitalism, New York: New Press.

Jagiełło, M., 2010. Narody i narodowości. Przewodnik po lekturach, t. I, Warszawa: Wyd. Uniwersytetu Warszawskiego. 
Jessop, B., Brenner, N. and Jones, M., 2008. Theorizing Sociospatial Relations, Environment and Planning D: Society and Space, vol. 26, pp. 389-401.

Jones, S., 2006. Antonio Gramsci, London-New York. Routledge.

Kubiak, H., 2007. U progu ery postwestfalskiej. Szkice z teorii narodu, Kraków: Universitas.

Lyotard, J.-F., 1984. The Postmodern Condition: A Report on Knowledge, (trans. Bennington, G. and Massumi, B.), Minneapolis: University of Minnesota Press.

Massey, D., 1993. Power-Geometry and a Progressive Sense of Place, [in:] Bird, J. et al. (eds), Mapping the Futures: Local Cultures, Global Change, London: Routledge, pp. 59-69.

Mamzer, H., 2007. W poszukiwaniu tożsamości. Humanistyczne rozważania interdyscyplinarne, Poznań: Wyd. UAM.

Markowski, D., 2004. Naródi państwo w socjologicznej perspektywie wieku globalizacji, [in:] Gorlach, K. et al. (eds), Władza, naród, tożsamość, Kraków: Wyd. Uniwersytetu Jagiellońskiego.

Martins, H., 1974. Time and Theory in Sociology, [in:] Rex, J. (ed.), Approaches to Sociology, London: Routledge and Kegan Paul, pp. 246-294.

Meyer, B., and Geschiere, P. (eds), 1999. Globalization and Identity: Dialectics Between Flow and Closure, London: Wiley-Blackwell.

Miller, J., 1998.Rejectamenta, [in:] Miller, J. and Schwartz, M. (eds), Speed, London: Photographers' Gallery.

Mittelman, J.H., 2000. The Globalization Syndrome: Transformations and Resistance, Princeton: Princeton University Press.

Morse, M., 1998. Virtualities: Television, Media Art and Cyberculture, Bloomington: Indiana University Press.

ÓTuathail, G., 1998. Political Geography III: Dealing with Deterritorialization, [in:] Progress in Human Geography, vol. 22, no 1, pp. 81-93.

Papastergiadis, N., 2000. The Turbulence of Migration: Global, Deterritorialization, and Hybridity, Cambridge: Polity.

Robertson, R., 1992. Globalization: Social Theory and Global Culture, London: Sage.

Rosenau, J., 1990. Turbulence in Foreign Politics: A Theory of Change and Continuity, Princeton: Princeton University Press.

Rosenau, J., 1997. Along the Domestic-Foreign Frontier: Exploring Governance in a Turbulent World, Cambridge: Cambridge University Press.

Rouse, R., 1995a. Questions of Identity: Personalhood and Collectivity in Transnational Migration to the United States, Critique of Anthropology, vol. 15, no 4, pp. 351-380.

Rouse, R., 1995b. Thinking through Transnationalism: Notes on the Cultural Politics of Class Relations in the Contemporary United States, Public Culture, no 7, pp. 353402. 


\section{Jan Rek}

Sayer, A., 2000. Realism and Social Science, London: Sage.

Scholte, J.A., 2000. Globalization: A Critical Introduction, London: Palgrave Macmillan.

Scholte, J.A., 2008. Defining Globalization, The World Economy, vol. 31, no 11, pp. 14711502.

Sinclair, J. et al. (eds); 1996. New Patterns in Global Television: Peripheral Vision, Oxford: Oxford University Press.

Skarga, B., 1997. Tożsamość i różnica. Eseje metafizyczne, Kraków: Znak.

Stephens, J. and McCallum, R., 1998. Retelling Stories, Framing Culture: Traditional Story and Metanarratives in Children's Literature, London: Routledge.

Storey, D., 2003. Territory: the Claiming of Space, New York: Prentice Hall.

Strange, S., 1999. The Defective State, Daedalus, vol. 124, no 2, pp. 55-74.

Szacki, J., 1997. O narodzie i nacjonalizmie, Znak, no 502.

Szacki, J., 2004. O tożsamości (zwłaszcza narodowej), Kultura i Społeczeństwo, no 3.

Szlachcicowa, I., 2007. Tożsamość ponowoczesna. O poszukiwaniach teoretycznych w kontekście metodologicznym, [in:] Leoński, J. and Kozłowska, U. (eds), W kręgu socjologii interpretatywnej. Badania jakościowe nad tożsamościa, Szczecin: Economicus.

Taylor, P.J., 1994. State as Container: Territorialism in the Modern World-System, Progress in Human Geography, vol. 18, no 2, pp. 151-162.

Taylor, P.J., 1996. Embedded Statism and the Social Sciences: Opening Up to New Spaces, Environment and Planning, vol. 28, no 11, pp. 1917-1928.

Taylor, P.J., 2000. World Cities and Territorial States Under Conditions of Contemporary Globalization, Political Geography, vol. 19, no 1, pp. 5-32.

Tester, K., 2004. The Social Thought of Zygmunt Bauman, London: Palgrave and Macmillan.

Wallerstein, I., 1988. Inventions of TimeSpace Realities: Towards an Understanding of Our Historical Systems, Geography, vol. 73, no 4, pp. 289-297.

Wallerstein, I., 1991. Unthinking Social Science. The Limits of $19^{\text {th }}$ Century Paradigms, New York: Cambridge University Press.

Wassmann, J., 1998. Introduction, [in:] Wassmann, J. (ed.), Pacific Answers to Western Hegemony: Cultural Practices of Identity Construction, Oxford-New York: Berg Publishers.

Williams, R., 1983. Towards 2000, London: Chatto and Windus.

Wimmer, A. and Glick Schiller, N., 2002. Methodological Nationalism and Beyond: Nation-State Building, Migration, and the Social Sciences, Global Networks, vol. 2, no 4, pp. 301-334.

Wnuk-Lipiński, E., 2004. Świat międzyepoki: globalizacja, demokracja, państwo narodowe, Kraków: Znak. 